\title{
Lógicas das mídias da sociedade civil organizada (SCO) quando trabalham o tema ambiental na ótica informativo-jornalística
}

\author{
Logics of the media of organized civil society (SCO) when working on the \\ environmental issue in the informative-journalistic optics \\ Logique des médias de la société civile organisée (SCO) en travaillant sur la \\ question de l'environnement d'un point de vue informatif-journalistique
}

Lógicas de los medios de comunicación de la sociedad civil organizada (SCO)
cuando trabajan el tema ambiental bajo la óptica informativa-periodística

Jane Marcia Mazzarino ${ }^{1}$

Recebido em 10/10/2017; revisado e aprovado em 24/01/2018; aceito em 26/01/2018

DOI: http://dx.doi.org/10.20435/inter.v0i0.1733

\begin{abstract}
Resumo: Estão emergindo formas alternativas nas mídias das organizações da sociedade civil organizada (SCO) quando trabalham na ótica informativo-jornalística ou as práticas remetem às lógicas tradicionalizadas pelo campo jornalístico? O objetivo deste artigo é refletir sobre as lógicas das mídias da sociedade civil organizada (SCO) quando abordam o tema ambiental na ótica informativo-jornalística. Abordam-se elementos da interface entre estudos de comunicação midiatizada e SCO utilizando-se a revisão bibliográfica.
\end{abstract}

Palavras-chave: sociedade civil organizada; midiatização; informação jornalística.

Abstract: Are alternative forms emerging in the media in organizations of the organized civil society (SCO) when they work in the informative-journalistic optics or the practices refer to the logics traditionalized by the journalistic field? The objective of this article is to reflect on the logics of organized civil society (SCO) media when they approach the environmental theme from an informative-journalistic point of view. Elements of the interface between mediated communication studies and SCO are deepened using the bibliographic review. Keywords: organized civil society; mediatization; journalistic information.

Résumé: Des formes alternatives émergent-elles dans les médias des organisations de la société civile organisée (SCO) lorsqu'elles travaillent dans la perspective informative-journalistique ou les pratiques se réfèrent-elles à la logique traditionnelle du domaine journalistique? L'objectif de cet article est de réfléchir sur les logiques des médias de la société civile organisée (SCO) en travaillant sur le thème de l'environnement d'un point de vue informatif et journalistique. Les éléments de l'interface entre les études de communication par médiation et SCO sont abordés dans la revue bibliographique.

Mots-clés: société civile organisée; médiatisation; informations journalistiques.

Resumen: Se pregunta si están emergiendo formas alternativas en los medios de las organizaciones de la sociedad civil organizada (SCO) cuando trabajan en la óptica informativa-periodística O las prácticas remiten a las lógicas tradicionalizadas por el campo periodístico? El objetivo de este artículo es reflexionar sobre las lógicas de los medios de la sociedad civil organizada (SCO) cuando abordan el tema ambiental en la óptica informativa-periodística. Elementos de la interfaz entre estudios de comunicación mediática y SCO se profundizan utilizando la revisión bibliográfica.

Palabras clave: sociedad civil organizada; midiatización; información periodística.

\section{INTRODUÇÃO}

A sociedade civil organizada contemporânea, aqui compreendida como os movimentos sociais de todo tipo (incluindo-se as organizações não governamentais ativistas), escreve sua história em conexão crescente com a visibilidade midiática, tanto com uso de meios próprios como pautando os veículos tradicionais comerciais.

\footnotetext{
${ }^{1}$ Universidade do Vale do Taquari (Univates), Lageado, Rio Grande do Sul, Brasil.
} 
Uma análise evolutiva desse processo de midiatização, compreendendo as últimas décadas, aponta que muita coisa mudou, especialmente em decorrência do avanço tecnológico. Ao caracterizar a comunicação feita pelas organizações da sociedade civil, Bona (2006) afirma que, nos anos 1960, a divulgação utilizava-se de iniciativas alternativas e populares (teatro, cartazes, sensibilizações, passeatas e folhetos). Na década de 1980, avança-se para o profissionalismo, com planejamento estratégico das atividades comunicacionais e solicitação de recursos, junto a fontes diversas, para efetivação de projetos. Nos anos 1990, a parceria com o Estado concretiza-se, sucedida pela busca de apoio dos meios de comunicação e pela profissionalização no tratamento da comunicação (com contratação de assessores de imprensa e investimento em capacitação).

As possibilidades comunicativas ampliam-se nos anos $2000 \mathrm{com}$ a rede mundial de computadores e as redes sociais; consequentemente, as conversas pautadas pela temática ambiental presentificam-se de modo crescente no cotidiano das pessoas, e é possível, então, usar a informação ambiental de modo amplo, mas diferenciado das mídias comerciais.

Compreende-se que os relatos midiáticos da Sociedade Civil Organizada (SCO) constituem-se em si mesmos modos de participação na semiose social, conceito tomado de Verón (1996, p. 125). Para o autor, com a mídia, amplia-se a rede semiótica, entendida como um sistema produtor de sentidos que forma uma semiose social "condição de funcionamento de uma sociedade em todos seus níveis". Cada emissor-receptor insere seus relatos na rede e, assim, dinamiza a semiose social, ressignificando as conversas sociais, posicionando-se em relação às "novidades" que surgem para suas pautas.

Mazzarino (2013) analisa a semiose como algo relativo tanto ao campo midiático como aos demais, entre eles o dos movimentos sociais, os quais, quando dão visibilidade pública aos seus discursos sobre temas de seu interesse, instituem uma arena de disputas e negociações por meio de estratégias e práticas diversas, formando uma intersecção gramatical complexa. A semiose de sentidos caracteriza-se por relações que formam e estruturam as redes sociocomunicacionais, determinando padrões de interação, os quais são demarcados por matrizes culturais que se misturam constituindo pachworks de sentidos (MAZZARINO, 2013, p. 116-7).

Quando essa semiose é mediada pelas Tecnologias de Informação e Comunicação (TICs) determinam a formação da tecnocultura ou do bios midiático, quando saber e sentir passam a ser mediados pelas tecnologias (SODRÉ, 2002). Esse processo, denominado por Sodré (2002) e Verón (1997) de midiatização, determina mudanças culturais que são, ao mesmo tempo, geradoras de um novo sentido para a realização e para a ação humana, como também para a organização das situações cotidianas.

Um dos aspectos relevantes na midiatização dos acontecimentos é que os produtores das notícias enquadram sentidos, como que para fazer ver a realidade ao seu modo. Mendonça e Simões (2012) partem de Gregory Bateson e Erving Goffman para trabalhar sobre o conceito de enquadramento e apontam que são marcas presentes nos enunciados, que balizam a interação, indicando aos sujeitos modos de agir, posicionar-se, que podem ser negociados, afirmados, negados, modificados, sustentados, introduzidos. Os enquadramentos moldam relações (situação comunicativa), interpretações (conteúdo discursivo) e efeitos.

É, nesse cenário, que surge a problemática sobre a qual se quer refletir. Observa-se que as organizações da SCO têm a possibilidade, com as TICs, de construir seus próprios modos de fazer, paralelos e alternativos às mídias comerciais tradicionais, já que tem a sua disposição 
canais próprios de mídia, por meio dos quais oferta suas formas de fazer ver aspectos da realidade social, relativos às temáticas com as quais se voltam. Assim, podem dar visibilidade às suas noções de verdade, sem filtros, comunicando-se diretamente com os interlocutores que escolhem como seus públicos.

Mas como isso está acontecendo? Estão emergindo formas alternativas nas mídias das organizações da SCO quando trabalham na ótica informativo-jornalística ou as práticas remetem às lógicas tradicionalizadas pelo campo jornalístico? Quais potencialidades se podem vislumbrar para a comunicação midiatizada das organizações ambientalistas da SCO com as TICs? O objetivo deste artigo é refletir sobre as lógicas expostas nas mídias da SCO quando trabalham o tema ambiental na ótica informativo-jornalística.

A abordagem se dá na interface entre a comunicação midiatizada e a SCO, para o que se utilizou a revisão bibliográfica realizada a partir de autores que têm centrado seus estudos em organizações ambientalistas. Na plataforma Scielo não foram encontrados artigos que abordem essa relação, em uma busca feita em 22 de dezembro de 2017, que compreende todo o tempo de publicação da plataforma. Quando se utilizaram as palavras de busca "organizações ambientais" e "organização ambiental", apareceram 246 artigos, dos quais nenhum se debruça sobre a problemática proposta neste estudo. Com a palavra "movimentos ambientais", não há nenhum registro, já quando se usa o termo "movimento ambiental" surgem 102 artigos, dos quais apenas um trata da interação das organizações ambientalistas com o campo midiático. O artigo de Mazzarino (2008), no entanto, analisa como uma organização socioambiental atua como fonte do campo jornalístico, enquadrando seus discursos para dar visibilidade às suas agendas, especialmente as de cunho ambiental. Portanto não se refere a um estudo sobre a midiatização da informação jornalística produzida pelas organizações e veiculadas em suas mídias, foco deste artigo.

A busca por produção científica relacionada à problemática exposta trouxe resultados quando feita em eventos científicos da área da comunicação, caso do Congresso Brasileiro de Ciências da Comunicação (Intercom) e do Congreso Latinoamericano de Investigadores de la Comunicación (Alaic), entre 2002 a 2012. Desses eventos, foram selecionados artigos que se mostraram relevantes pela profundidade da abordagem ou por trazerem aspectos diversos para pensar as relações que se propõe. Além dessas referências, foram utilizadas produções bibliográficas relacionadas aos temas de interface que se discute.

Evidenciou-se uma situação de carência de estudos que articulem a midiatização da informação jornalística por organizações ambientalistas da SCO, o que mostra a relevância deste artigo. Considera-se, ainda, a necessidade de uma reflexão sobre as possibilidades abertas para atores coletivos contra-hegemônicos com a insurgência das TICs e suas diversas facetas, assim como de uma observação atenta desse fenômeno social, de modo a compreender os modos de apropriação feitos por essas organizações.

Como resultados, apresentam-se reflexões sobre a relação entre tecnologias e a cultura ambiental, como também sobre acesso, mediação e interatividade, elementos que emergiram como focos nas produções científicas em que este artigo se baseia. Além disso, ao fim, se apresentam duas hipóteses sobre as lógicas da SCO quando esta protagoniza processos de midiatização da informação jornalística de cunho ambiental. 


\section{TECNOLOGIAS E CULTURA AMBIENTAL}

A transformação dos valores passa necessariamente pela sua visibilidade, seja por meio das TICS ou das interações não mediadas por esses instrumentos. Em relação às questões ambientais, os valores de índole pós-materialistas têm sido colocados em pauta pelos movimentos sociais ambientalistas desde os anos 1960, constituindo um processo de contracultura em relação aos valores dominantes. Essas dinâmicas comunicacionais e culturais foram analisadas por sociólogos como Touraine e Melucci.

Touraine (1992) afirma que os movimentos sociais são agentes coletivos que buscam a mudança dos valores vigentes em uma sociedade, ofertando outras orientações culturais. Portanto, para ele um movimento social é antes de tudo um movimento cultural, que tem como razão de ser a disputa de sentidos, o que caracteriza a formação de uma arena simbólica conflituosa. Busca-se, assim, controlar as ações de transformação da sociedade sobre si mesma por meio de modelos culturais que se superam continuamente, o que Touraine define como um processo de historicidade. A mesma perspectiva simbólica é ressaltada nas contribuições teóricas de Melucci (2001), autor que afirma ser a natureza dos movimentos sociais basicamente comunicacional, retratada nos sentidos das mensagens que colocam em circulação pelas próprias ações como por outros meios.

Os processos de comunicação em que as organizações da SCO se envolvem, dizem sobre suas propostas de sentidos para as temáticas em debate e, portanto, requerem ser estudados a partir dos fluxos de informação em circulação nas mídias dessas organizações. Isto porque é nesse âmbito que a SCO tem autonomia na escolha dos temas que coloca em debate, pautando-os em seus espaços midiáticos. Desse modo, busca agendar as conversas sociais com os significados que constrói, muitas vezes, sendo promotora dos acontecimentos que midiatiza. Nesse caso, trata-se de um fazer interessado explícito, em que o ativismo se entrelaça às lógicas midiáticas.

O uso das TICs é parte do jogo de forças sociais, com suas possibilidades de informar, afetar, polemizar, criar acontecimentos, intervir, gerar movimentos. Para isso, a SCO vale-se das múltiplas ferramentas disponibilizadas pelos suportes midiáticos digitais. Esse movimento, que se iniciou na década de 1990, ganhou força gradativamente na sociedade mundial e fez com que as inovações tecnológicas transformassem os processos de comunicação da SCO, possibilitando a organização em rede e a circulação de informação, provocando, desse modo, engajamento no processo de disputa de sentidos sobre o contexto ambiental. Autores como I. Santos e Aguiar (2012), S. Santos e Aguiar (2012), Miguel (2007, 2010), Pinto e Fossá (2012) e Fossá e Pinto (2011) debruçaram-se sobre esses aspectos no estudo de casos de organizações ambientalistas.

I. Santos e Aguiar (2012) e S. Santos e Aguiar (2012) observaram, em estudo empírico, que a estruturação de Organizações Não Governamentais (ONGs) em rede potencializa a participação, o acúmulo de conteúdo, a construção das imagens organizacionais, além de afirmar a representatividade e a legitimidade pública das organizações por meio da visibilidade midiática, mobilizando apoio às suas causas. As mídias sociais, nesse sentido, servem como uma estratégia de aproximação entre as organizações e delas com os públicos com os quais quer interagir.

Miguel, em estudo sobre ONGs ambientalistas, considera que o "movimento ambiental é um dos principais responsáveis pela proliferação das temáticas ambientais, tanto nos veículos de comunicação, como na agenda pública", o que vai evidenciar uma identidade midiatizada. Especificamente em relação às ONGs, afirma que estas contribuem no processo de informação 
ambiental porque "tornaram-se referência na questão ambiental, são exaustivamente procuradas como fontes de informações, formuladoras de conceitos, de novas diretrizes e pautas para a imprensa" (MIGUEL, 2007, p. 1-2).

Para Fossá e Pinto (2011), essa visibilidade que os movimentos sociais buscam possibilita sua participação na esfera pública, por meio da aparição na cena midiática, agendando, assim, temas e enquadramentos, convocando vontades, afetando imaginários, constituindo argumentos que incidem sobre sua credibilidade. Desse modo, liberam intencionalidades discursivas antes abafadas pelos meios hegemônicos. As autoras, em outro artigo, afirmam que a sociedade em rede possibilitada pelas TICs desencadeia um exercício de influência da cena política que amplia e flexibiliza os lugares de produção discursiva. "O ativismo, [...] vem ao encontro de duas premissas dos movimentos sociais: mobilizar os indivíduos e dar visibilidade às suas ações" (PINTO; FOSSÁ, 2012, p. 9). E é a visibilidade, segundo as autoras, que justifica a sua causa, legitimando-a e subsidiando sua atuação.

Para Miguel, as TICs "propiciam o desenvolvimento de modelos comunicativos, que modificam as estratégias institucionais de gestão, regulação e organização do conhecimento, constituindo um campo estratégico de transformações culturais" (MIGUEL, 2010, p. 6). A autora denomina como "cidadãos intermediários" aqueles que não atuam na dinâmica industrial de produção da informação, fugindo às regras ou controles formalizados. Esse tipo de comunicação "minimiza a constituição oligopólica das indústrias de comunicação, a partir da criação de novos meios de expressão" (MIGUEL, 2010, p. 6).

Desse modo, a autora entende que a rede de computadores oferece espaço para as organizações construírem sua própria identidade e exporem preocupações e iniciativas da sociedade, mas também podem reforçar padrões dominantes. "É certo que o ciberespaço está centrado em uma comunicação não necessariamente midiática, mas interativa, comunitária, transversal e rizomática, que engloba diferentes culturas e toda a diversidade e pluralidade que o conceito pressupõe" (MIGUEL, 2010, p. 9). Desse modo, ela defende que se busque compreender empiricamente as incursões do movimento ambientalista no contexto multicultural das TICs.

\section{ACESSOS: MEDIAÇÃO E INTERATIVIDADE}

É preciso reconhecer, de antemão, a crescente disseminação das TICs, assim como a ampliação de seu uso pelos movimentos sociais e a sua potencialidade, enquanto espaço alternativo para formação da opinião pública, paralelo às mídias tradicionais. No entanto, para muitas organizações, ainda é um desafio tanto a mediação quanto o possibilitar a interatividade por meio de suas mídias digitais.

As organizações precisam atentar para não apenas ofertar um espaço para postagem de informações, mas também mediar debates sobre temas públicos, o que requer o uso planejado e estratégico das potencialidades abertas com a internet. Sobre isso concordam dois estudos: de Peres e Cortez (2009) e de Rodrigues e Sinval (2011).

Peres e Cortez (2009) trazem a noção de espaço mediador, defendida por Cortez em sua tese de doutoramento. O conceito refere-se à mídia menos como veículo e mais como espaço de comunicação. O termo veículo tenderia a restringir o pensamento ao aspecto instrumental da mídia. Já o "espaço mediador é constituinte e gerado na sociedade para que ela possa se organizar e ter procedimentos e práticas que construam o tempo e o espaço no convívio social e 
na vida cotidiana" (PERES; CORTEZ, 2009, p. 4). No entanto esse espaço também é de conflitos, o que é inerente às situações de comunicação, que expõem diferentes visões de mundo. Para os autores, não se trata de um espaço neutro, acolhedor ou igualitário, mas sim um campo de luta e de mediação, passível de omissões, manipulações e distorções. "A capacidade de aglutinar e acolher apostos, dissonantes e desiguais Ihe dá uma dimensão de instituição capaz de reivindicar para si uma amplitude cultural, no sentido de ser um organizador das forças que transformam o processo cultural" (PEREZ; CORTEZ, 2009, p. 4).

Os autores argumentam que, quando se fala em comunicação ambiental, deve-se falar de como grupos motivados com preocupações ambientais podem constituir espaços de mediação cultural. A mediação requer mais que a divulgação: "implica capacidade de aglutinar o debate e as contradições, ainda com um formato e um filtro inerente à subjetividade dos atores" (PERES; CORTEZ, 2009, p. 9). A mediação cultural nos espaços midiáticos requer pautas e fontes polissêmicas, de modo a dar conta da diversidade cultural e da variedade de demandas sociais, defendem.

No entanto a mediação e a interatividade ainda aparecem como desafios no uso das mídias digitais pela SCO. Miguel (2011, p. 4), em seu estudo do portal do Greenpeace, afirma que o aspecto colaborativo não se mostrou decisivo, já que o conteúdo foi centralizado e filtrado, pois o internauta podia se cadastrar como usuário ou ciberativista, assinar petições e apoiar manifestos, mas sua opinião só era visibilizada "por meio de ferramenta de comentários para usuários cadastrados". A autora afirma, categoricamente, que a interatividade é "difundida, mas pouco avaliada", já que "vai além da disponibilização de um canal de retorno".

Miguel ressalta que "intensas transformações culturais e comunicativas foram possibilitadas pelos fenômenos tecnológicos" e, com isso, a causa ambiental ampliou sua visibilidade social. No entanto a autora sugere a necessidade de aperfeiçoamento dos mecanismos "de interatividade e atuação pela rede de computadores", já que as práticas ciberativistas comprovam que é possível a mobilização e o uso de táticas políticas que mostram-se decisivas e, portanto, merecem ser estudadas pelo campo da comunicação (MIGUEL, 2011, p. 10).

Em estudo que descreve o funcionamento das ferramentas virtuais presentes na página do Greenpeace, Miguel conclui que "a cibercultura ambientalista é um fenômeno social recente que busca a interação, consegue ampliar de forma imensurável o alcance e a importância da causa, conquista adeptos, faz alertas, mas acaba por reiterar paradigmas da mídia convencional" (MIGUEL, 2010, p. 14). Isto porque insiste no tom sensacional, explora o alarde, faz uso de informações descontextualizadas, deixando a desejar em relação à interatividade. Em seu estudo, a autora deparou-se com possibilidades pouco exploradas, como teleconferência, documentos abertos e construídos comunitariamente por meio de comunicação coletiva. A tendência que ela identificou no portal do Greenpeace é de "interatividade restrita a encaminhamento de mensagens, assinatura e petições e comentários" (MIGUEL, 2010, p. 14).

Apesar das limitações que observa, Miguel (2011) entende que os usuários passam a produzir e mobilizar informações em um cenário que prega o envolvimento, a troca, a colaboração, a interatividade e a mobilização, o que proporciona possibilidades variadas de interatividade, muitas delas ainda pouco experimentadas. Mesmo com limitações, a interação proporcionada pela internet é aproveitada pelos movimentos ativistas para contestar e lutar em um espaço paralelo às mídias tradicionais, que, historicamente, negaram a exposição das causas sociais (MASCARENHAS; AZEVEDO; TAVARES, 2009). 
Além de problemas de mediação cultural e interatividade, fatores que estão intrinsecamente relacionados, estudos empíricos apontam outros problemas na midiatização das ONGs. Miguel e Mazzarino (2015), Cortez e Roque (2012), Barreto (2008) identificaram como limitações no uso das TICs por ONGs: fragilidade de contextualização, pouca diversidade de fontes, com as ONGs colocando-se como fontes principais, e a tendência a adotar um foco institucional no uso da mídia para oferta de informação.

\section{LÓGICAS INFORMATIVO-JORNALÍSTICAS DA SCO: DUAS HIPÓTESES}

Quando se reflete sobre as lógicas informativo-jornalísticas da SCO a partir da perspectiva da área emergente da comunicação ambiental, é possível fazer uma crítica à idealização feita pelo espaço da web que, muitas vezes, gera deslumbramentos. Na sociedade em que impera a exigência de visibilidade e circulação de informação, o acesso em termos de equipamentos e sinais ainda é bastante desigual. Quando essa limitação é superada, a falta de diversidade de fontes remete a uma visão de mundo pouco plural, senão viciada, já que, ao se eliminar a alteridade discursiva, as chances de politização por meio de processos de comunicação ambiental diminuem.

Os estudos apontam que as ONGs ambientalistas ainda exploram parcialmente as possibilidades oferecidas pelas ferramentas da web para engajar nas suas agendas e enquadramentos, mesmo quando têm autonomia para definirem pautas e fontes, tipos e frequências nas publicações em um veículo que tem custo baixo. Com o uso das TICs, as organizações podem fazer ressonância crítica às pautas da mídia hegemônica e colocar em circulação modos de fazer alternativos, já que seu uso pode ser personalizado, sendo possível explorar mais livremente as narrativas.

A primeira hipótese que surge é que, no movimento ambientalista, o ativismo social não é acompanhado do ativismo midiático, com isso o ativismo político se enfraquece. Esse efeito de sentido decorre da reflexão sobre as proposições teóricas e os estudos empíricos apresentados, os quais apontam elementos para a compreensão da midiatização dos temas ambientais pela SCO. Por um lado, encontram-se as possibilidades das Tecnologias de Informação e Comunicação (TICS) para visibilizarem orientações culturais focadas na transformação social, já que, além de informar, a SCO pode criar acontecimentos e promover práticas colaborativas e o engajamento para com as suas causas, influenciando politicamente a sociedade, por ter o poder de constituir espaços alternativos de formação da opinião pública. Por outro lado, os estudos apontam que as organizações enfrentam como desafio a necessidade de aprenderem a mediar o debate para que se efetivem práticas políticas a partir dos seus espaços midiáticos, assim como de qualificarem as formas de gerar interatividade, de modo a agirem como mobilizadores e organizadores das forças sociais, evitando repetir os modos de fazer midiáticos dos meios convencionais (TOURAINE, 1992; MELUCCI, 2001; I. SANTOS; AGUIAR, 2012; S. SANTOS; AGUIAR, 2012; MIGUEL, 2007, 2010, 2011; PINTO; FOSSÁ, 2012; FOSSÁ; PINTO, 2011; PEREZ; CORTEZ, 2009; RODRIGUES; SINVAL, 2011; MASCARENHAS; AZEVEDO; TAVARES, 2009; MIGUEL; MAZZARINO, 2015; CORTEZ; ROQUE, 2012; BARRETO, 2008; CUNHA, 2006; HENNIGEN; RODRIGUES, 2011).

Mazzarino (2015) observou que a SCO, muitas vezes, refaz o caminho das práticas tradicionais do jornalismo, ao inverso: a mídia hegemônica legitima sua versão dos fatos com seus próprios especialistas e fontes oficializadas que se repetem e, da mesma forma, as ONGs exploram suas próprias versões e de poucos especialistas. A autora chegou a essa conclusão ao 
analisar o uso das mídias próprias de ONGs ambientalistas, e o mesmo foi percebido no caso da midiatização de comitês de bacias hidrográficas e sites governamentais especializados na questão da água. Ao comparar com outros estudos realizados em mídias comerciais, a autora percebeu semelhanças entre os quatro grupos analisados em relação ao uso de fontes e à superficialidade da abordagem. As vozes permitidas são das fontes que compartilham pontos de vista sobre os temas, o que reduz a pluralidade na abordagem. E, no caso da SCO, tendem a ser a voz das próprias organizações.

Portanto, do mesmo modo que Cunha (2006) observa que, nos meios convencionais, a cultura jornalística aprisionou o jornalismo à repetição de formas, linguagens e técnicas, os modos de noticiar da SCO também tendem a reproduzir as lógicas da cultura jornalística (MAZZARINO, 2015; MIGUEL; MAZZARINO, 2015; CORTEZ; ROQUE, 2012; BARRETO, 2008). Certo é que, contemporaneamente as TICs desafiam produtores de notícias de ambos os campos (jornalístico e dos movimentos sociais) com suas múltiplas possibilidades de criar, entreter, informar, seduzir, afetar e criar efeitos estéticos, por meio de possibilidades multimidiáticas que potencializam o envolvimento do receptor e, quem sabe, sua sensibilização para a problemática ambiental.

As possibilidades abertas pelo jornalismo colaborativo podem vir a significar para o processo de produção, circulação e recepção da informação ambiental, a partir das mídias próprias da SCO, a realização da mediação cultural, interação e engajamento politizado e sensível às causas ambientais. Se o processo de midiatização implica a produção de subjetividades, por meio de pedagogias culturais incrustadas em um discurso jornalístico que dá indicativos de um dever ser não ser, que acaba instituindo uma forma de controle da subjetividade, afetando modos de existência, de valorar e de viver (HENNIGEN; RODRIGUES, 2011), ao se retomar o questionamento que move este artigo,- relativo às possibilidades de exploração das TICs pelas organizações da SCO quando trabalham na ótica informativo-jornalística- apesar de suas lógicas se aproximarem, em vários aspectos, das lógicas tradicionais do campo jornalístico, evidencia-se que o uso das mídias pela SCO tem a potência de propiciar novas formas de interação, participação e cocriação de sentidos, assim como novos conflitos decorrentes dessas visibilidades e, também, outros modos de resolvê-los.

Portanto o que se espera do processo de produção de notícias pela SCO é o mesmo desejo que se acalenta em relação ao jornalismo público ou cívico. Ambos surgem movidos pelo interesse coletivo e têm compromisso com a revitalização da cidadania. Mas, para que esses ideais se efetivem, é preciso superar algumas das limitações apontadas.

Para isso, se requer um uso mais estratégico do descentramento decorrente da possibilidade de ter as próprias mídias. Há também muito a se explorar em relação às significações a serem ofertadas dos acontecimentos ambientais, aos posicionamentos em relação aos temas e às conversas sociais possíveis de serem estimuladas pelos atores da SCO.

Quando discursos alternativos tomam a cena nos processos de midiatização, afetam a cultura ambiental em construção, dinamizando a semiose social. Quando ainda muitas incertezas pairam sobre a problemática ambiental, as organizações precisam ter a compreensão de que sua narrativa dos acontecimentos ambientais são formas de mediar e enquadrar saliências para o receptor. As saliências, assim como os silenciamentos, são indicativos do que deve fazer ou pode vir a fazer parte da agenda de debate ambiental.

Muitas agendas circulam e influenciam-se mutuamente na sociedade (MC COMBS, 2009), dentre elas se observa o crescente poder ou a emergente possibilidade de as agendas do mo- 
vimento ambientalista fazerem cada vez mais parte dos processos de comunicação pública, o que, quando há o uso estratégico das TICs, pode ressoar com muito mais força. Trata-se de uma segunda hipótese, que é reforçada pela percepção de Castells (2009), que percebe que as ações ecologistas se fortalecem e aumentam sua influência pública com o ativismo orientado para o uso das possibilidades ofertadas com a Internet. Para Castells (2013), vive-se um fenômeno que ele denomina de "autocomunicación de masas". Sua característica essencial é a disseminação de informação de forma individualizada e horizontal, de muitos para muitos, o que dificulta seu controle, oportunizando processos autônomos para atores individuais e coletivos difundirem mensagens e imagens, ampliando as possibilidades de mudanças políticas e culturais.

\section{CONSIDERAÇÕES FINAIS}

Este artigo, baseado em autores que estudam os processos de midiatização por organizações ambientalistas, apontam indícios que o poder de uso das TICs articulado em uma proposta de autocomunicação, em que as organizações, em uma prática autônoma, assumem concomitantemente os papéis de emissores e receptores de discursos em circulação, formando uma semiose social infinita pouco passível de regulação discursiva, ainda não está sendo explorado amplamente pela SCO.

Quando se parte de uma visão da ciência enquanto campo entremeado de complexidades (MORIN, 1996, 2001), certamente os apontamentos não são generalizáveis, pois decorrem de reflexões a partir dos ainda incipientes e parcos estudos sobre midiatização das organizações ambientalistas e, desse modo, estão atravessados por limites e incertezas. No entanto permitem vislumbrar nuances e potencialidades do que os fenômenos deixam ver de si, apesar de suas indeterminações, decorrentes de cruzamentos discursivos múltiplos enquadrados e/ou visibilizados nos espaços midiáticos apropriados pelas organizações da SCO que se orientam por temas ambientais.

Verificou-se que as novas tecnologias de informação potencializaram novas formas de comunicação que ora são utilizadas estrategicamente, ora não pelos atores. Mas como os estudos nessa vertente ainda não se avolumam, trata-se de um campo promissor para aprofundamentos.

Isto porque as novas mídias possibilitam ampliar o debate e as possibilidades de orientação social sobre temas ambientais tornados públicos, por meio de múltiplos canais e modos de exposição discursiva, que podem inclusive convergir, apoiando-se mutuamente em suas ênfases discursivas. Mídias da SCO e de receptores comuns podem agora colaborar na construção das agendas sociais. Esse novo cenário faz com que estudar a circulação - zona de contato entre produção e recepção - se torne um espaço especialmente interessante de análise.

Para aprofundar a compreensão das limitações na relação da SCO com as TICs entende-se que devam ser empreendidos, ainda, estudos sobre o processo produtivo das notícias por essas organizações, no que incidem aspectos relativos à interação entre os diferentes atores envolvidos nesse fazer, além de questões organizacionais (política, gestão, estrutura, conflitos etc.).

Por fim, apesar de se reconhecer as limitações no uso das TICs, concorda-se com Zhouri quando afirma a força política de organizações da sociedade civil, por desafiarem formas tradicionais, especialmente a força das organizações ambientalistas, que tem em sua especialização técnica uma ferramenta necessária. "Todavia, um desafio futuro para os grupos ambientalistas será escapar do estado de assepsia provocado pelo distanciamento técnico-científico em relação 
aos contextos culturais locais que parece tê-los capturado, em última instância, na armadilha da atual agenda de mercado neoliberal" (ZHOURI, 2001, p. 39).

Para escapar a essa assepsia, o uso das TICs pela SCO precisará se encaminhar para um processo de comunicação caracterizada pelo compromisso com o interesse cidadão, que seja interpretativo e valorizador das vozes e versões múltiplas, de modo a potencializar o debate sobre os temas e o posicionamento político de modo, também, sensível. Portanto, no seu horizonte, pairam desafios comunicacionais, midiáticos e políticos, os quais não raramente se confundem.

\section{REFERÊNCIAS}

BARRETO, Bruno Augusto A. Política nuclear brasileira: o papel das ONGs WWF e Greenpeace na questão energética. In: CONGRESSO BRASILEIRO DE CIÊNCIAS DA COMUNICAÇÃO, 31., 2008, Natal, RN. Anais [...] Natal, RN: UFRN, 2008. Disponível em: http://www.intercom.org.br/papers/nacionais/2008/resumos/ R3-0555-1.pdf. Acesso em: 4 nov. 2014.

BONA, Nivea. O jornalista como uma ponte entre as organizações civis e a mídia de massa. UNIrevista, São Paulo, v. 1, n. 3, 2006.

CASTELLS, Manuel. Redes de indignação e esperança - movimentos sociais na era da internet. Rio de Janeiro: Zahar, 2013.

CASTELLS, Manuel. Comunicación y poder. Madrid: Alianza Editorial, 2009.

CORTEZ, Glauco Rodrigues; ROQUE, Maura Voltarelli. As fontes de informação na comunicação das ONGs ambientalistas. Revista Lumina, Juiz de Fora, MG, v. 6, n. 1, p. 1-19, jun. 2012.

CUNHA, Magda. Fatos rompem a moldura dos meios e valorizam papel do Jornalismo. UNIrevista, São Paulo, v. 1, n. 3, 2006.

FOSSÁ, Maria I. Trevisan; PINTO, Rafaela C. Movimentos sociais e minorias: apontamentos do ciberativismo do Greenpeace. In: CONGRESSO BRASILEIRO DE CIÊNCIAS DA COMUNICAÇÃO, 34., 2011, Recife. Anais [...]. Recife: UNICAP, 2011. Disponível em: http://www.intercom.org.br/papers/nacionais/2011/resumos/ R6-2959-1.pdf. Acesso em: 4 nov. 2014.

HENNIGEN, Inês; RODRIGUES, Luciana. Jornalismo, a questão da verdade e a produção de subjetividade. Arquivos Brasileiros de Psicologia, Rio de Janeiro, v. 63, n. 3, p. 45-57, 2011. Disponível em: http://pepsic. bvsalud.org/scielo.php?pid=S1809-52672011000400005\&script=sci_arttext. Acesso em: 9 mar. 2015.

MASCARENHAS, Alan; AZEVEDO, Ana P.; TAVARES, Olga. Ciberativismo: mídias digitais e o ativismo ambiental na rede. In: CONGRESSO BRASILEIRO DE CIÊNCIAS DA COMUNICAÇÃO, 32., 2009, Curitiba. Anais [...]. Curitiba: Universidade Positivo, 2009. Disponível em: http://www.intercom.org.br/papers/ nacionais/2009/resumos/R4-2234-1.pdf. Acesso em: 4 nov. 2014.

MAZZARINO, Jane Marcia. Das matrizes contraditórias do jornalismo ambiental a um novo critério de noticiabilidade: o interesse cidadão comunitário. Revista Comunicação Midiática (Online), Bauru, SP, v. 10, n. 3, p. 167-84, set./dez. 2015.

MAZZARINO, Jane Marcia. Tecelagens comunicacionais-midiáticas no movimento socioambiental. 1. ed. Lajeado, RS: Univates, 2013. v. 1, 404p.

MAZZARINO, Jane Marcia. Matrizes que se cruzam: interações entre movimento socioambiental e campo jornalístico. Ambiente \& Sociedade, Campinas, SP, v. XI, n. 1, p. 49-66, jan./jun. 2008. 
MC COMBS, Maxwell. Teoria da agenda: a mídia e a opinião públicas. Petrópolis, RJ: Vozes, 2009.

MELUCCI, Alberto. A invenção do presente. Petrópolis, RJ: Vozes, 2001.

MENDONÇA, Ricardo Fabrino; SIMÕES, Paula Guimarães. Enquadramento: diferentes operacionalizações analíticas de um conceito. Revista Brasileira de Ciências Sociais, São Paulo, v. 27, n. 79, p.187-201, jun. 2012.

MIGUEL, Katarini G.; MAZZARINO, Jane M. A crise da água no Facebook: estudo comparativo da comunicação em rede das ONGs ambientalistas. In: CONGRESSO BRASILEIRO DE CIÊNCIAS DA COMUNICAÇÃO, 38., 2015, Rio de Janeiro. Anais [...]. Rio de Janeiro: UFRJ, 2015. Disponível em: http://portalintercom.org.br/anais/ nacional2015/busca.htm?query=KATARINI. Acesso em: 25 abr. 2017.

MIGUEL, Katarini. Comunicação ambiental na sociedade digital: revelações empíricas iniciais. In: CONGRESSO BRASILEIRO DE CIÊNCIAS DA COMUNICAÇÃO, 34., 2011, Recife. Anais [...]. Recife: UNICAP, 2011. Disponível em: http://www.intercom.org.br/papers/nacionais/2011/resumos/R6-1583-1.pdf. Acesso em: 4 nov. 2014.

MIGUEL, Katarini. Estratégias de comunicação e mobilização na cibercultura ambientalista. In: CONGRESSO BRASILEIRO DE CIÊNCIAS DA COMUNICAÇÃO, 33., 2010, Caxias do Sul. Anais [...]. Caxias do Sul: UCS, 2010. Disponível em: http://www.intercom.org.br/papers/nacionais/2010/resumos/R5-2841-1.pdf. Acesso em: 4 nov. 2014.

MIGUEL, Katarini G. A expressão dos movimentos ambientais na atualidade: mídia, diversidade e igualdade. In: CONGRESSO BRASILEIRO DE CIÊNCIAS DA COMUNICAÇÃO, 30., 2007, Santos. Anais [...]. Santos: UNISANTOS, UNISANTA, UNIMONTE, 2007. Disponível em: http://www.intercom.org.br/papers/ nacionais/2007/resumos/R1143-1.pdf. Acesso em: 5 nov. 2014.

MORIN, Edgar. Introdução ao pensamento complexo. Lisboa: Instituto Piaget, 2001

MORIN, Edgar. Ciência com consciência. Rio de Janeiro: Bertrand Brasil, 1996.

PERES, Vanessa B.; CORTEZ, Glauco R. Jornalismo opinativo e informativo nas ONGs ambientalistas: um estudo sob a ótica do espaço mediador cultural. In: CONGRESSO BRASILEIRO DE CIÊNCIAS DA COMUNICAÇÃO, 32., 2009, Curitiba. Anais [...]. Curitiba: Universidade Positivo, 2009. Disponível em: http://www.intercom.org.br/papers/nacionais/2009/resumos/R4-2824-1.pdf. Acesso em: 4 nov. 2014.

PINTO, Rafaela C.; FOSSÁ, Maria Ivete T. Estratégias ativistas do Greenpeace para inclusão e ampliação da visibilidade e da discutibilidade da temática ambiental na esfera pública. In: CONGRESO LATINOAMERICANO DE INVESTIGADORES DE LA COMUNICACIÓN - ALAIC, 11., 2012, Montevideo. Anais [...]. Montevideo, 2012. Disponível em: http://alaic2012.comunicacion.edu.uy/sites/default/files/gt8_caetano_rafaela_0. pdf. Acesso em: 5 nov. 2014.

RODRIGUES, Abiglacy; SINVAL, Julianna F. Moura. Ciberativismo: a extensão da militância no espaço virtual. In: CONGRESSO BRASILEIRO DE CIÊNCIAS DA COMUNICAÇÃO, 34., 2011, Recife. Anais [...]. Recife: UNICAP, 2011. Disponível em: http://www.intercom.org.br/papers/nacionais/2011/resumos/R6-1016-1. pdf. Acesso em: 4 nov. 2014.

SANTOS, Iargo de S.; AGUIAR, Sonia. Legado e visibilidade na Rede de ONGs da Mata Atlântica. In: CONGRESSO BRASILEIRO DE CIÊNCIAS DA COMUNICAÇÃO, 35., 2012, Fortaleza. Anais [...]. Fortaleza: UNIFOR, 2012. p. 1-13. Disponível em: http://www.intercom.org.br/papers/nacionais/2012/resumos/ R7-1559-1.pdf. Acesso em: 4 nov. 2014. 
SANTOS, Sóstina S.; AGUIAR, Sonia. Estratégias de visibilidade e interação das redes ASA e GTA nas mídias sócias. In: CONGRESSO BRASILEIRO DE CIÊNCIAS DA COMUNICAÇÃO, 35.; 2012, Fortaleza. Anais [...]. Fortaleza: UNIFOR, 2012. p. 1-11. Disponível em: http://www.intercom.org.br/papers/regionais/ nordeste2012/resumos/R32-1108-1.pdf. Acesso em: 4 nov. 2014.

SODRÉ, Muniz. Antropológica do espelho. Petrópolis, RJ: Vozes, 2002.

TOURAINE, Alain. Crítica da modernidade. Lisboa: Piaget, 1992.

VERÓN, Eliseo. Esquema para el análisis de la mediatización. Revista Dialogos de la Comunicacion, Lima, Peru, n. 48, p. 9-17, 1997.

VERÓN, Eliseo. La semiosis social: fragmentos de una teoría de la discursividad. Barcelona: Gedisa, 1996.

ZHOURI, Andréa. Árvores e gente no ativismo transnacional. As dimensões social e ambiental na perspectiva dos campaigners britânicos pela Floresta Amazônica. Revista Antropologia, São Paulo, v. 44, n. 1, p. 9-52, 2001. Disponível em: http://www.scielo.br/pdf/ra/v44n1/5340.pdf. Acesso em: 5 nov. 2014.

\section{Sobre a autora:}

Jane Marcia Mazzarino: Doutora e mestre em Ciências da Comunicação e graduada em Jornalismo pela Universidade do Vale do Rio dos Sinos (Unisinos). Professora permanente no Programa de Pós-Graduação Ambiente e Desenvolvimento (PPGAD) e nos cursos de Comunicação Social da Universidade do Vale do Taquari (Univates), onde coordena o projeto de pesquisa-extensão Comunicação, Educação Ambiental e Intervenções (Ceami CNPq). E-mail: janemazzarino@univates.br, Orcid: http://orcid.org/0000-0002-6051-5116 